\title{
A systematic review of microsurgical reconstruction of the jaws using vascularized fibula flap technique in patients with bisphosphonate-related osteonecrosis
}

\author{
Roberto SACCO ${ }^{1}$, Gianluca SACCO ${ }^{2}$, Alessandro ACOCELLA ${ }^{3}$, Silvana SALE ${ }^{4}$, Nicola SACCO ${ }^{5}$, Edoardo BALDONI ${ }^{6}$ \\ 1- DDS, Oral Surgery Program Resident, Department of Odontostomathology, Faculty of Medicine, University of Sassari, Sassari, Italy. \\ 2- DDS, PhD, Oral Surgery Program Resident, Department of Odontostomathology, Faculty of Medicine, University of Sassari, Sassari, Italy. \\ 3- DDS, Oral Surgery Specialist, Department of Oral and Maxillofacial Surgery, Faculty of Medicine, University of Florence, Florence, Italy. \\ 4- DDS, PhD, Oral Surgery Program Resident, Department of Odontostomathology, Faculty of Medicine, University of Sassari, Sassari, Italy. \\ 5- MD, Private practice, Salerno, Italy. \\ 6- MD, DDS, Full Professor, Oral Surgery Program Director, Department of Odontostomathology, Faculty of Medicine, University of Sassari, Sassari, Italy.
}

Corresponding address: Roberto Sacco - Address: 17 A, London Road, Twickenham TW13SX, London (UK) - Phone: +39 $349-5858220$ (cell.) - e-mail: saccoroberto@yahoo.it

Received: July 22, 2009 - Modification: August 26, 2010 - Accepted: October 26, 2010

\section{ABSTRACT}

$\mathrm{O}$ bjective: The aim of this systematic review was to assess the role of microsurgical reconstruction of the jaws in patients with bisphosphonate-related osteonecrosis, and biological complications after an observation period of at least 12 months. Material and methods: An electronic MEDLINE search supplemented by manual searching was conducted to identify studies reporting data of at least 12 months observation on the microsurgical reconstruction of the jaws in patients with bisphosphonate-related osteonecrosis. Results: Four studies resulted eligible for the analysis yielded. Three out of five studies were free of complications, with a success rate of $100 \%$ as no recurrence of osteonecrosis was registered. Conclusions: Microsurgical reconstruction of the jaws represents a valid treatment modality in patients with bisphosphonate-related osteonecrosis at $3^{\text {rd }}$ stage of the disease.

Key words: Jaw diseases. Osteonecrosis. Bisphosphonates.

\section{INTRODUCTION}

Bisphosphonates are a new class of agents that have been increasingly recommended for use in patients with osteoporosis, Paget's disease of bone, hypercalcemia of malignancy, osteolytic bone metastases, and osteolytic lesions of multiple myeloma (Figure 1$)^{7,19}$. Despite the benefits related to use of these medications, osteonecrosis of the jaws is a significant complication in a subset of patients receiving these drugs in particular with intravenous administration. Based on a growing number of case reports and institutional reviews, bisphosphonate therapy may cause exposed and necrotic bone that is isolated to the jaw $^{33,35}$. This complication could present after simple dentoalveolar surgery. The phenomenon of bisphosphonate-related osteonecrosis of jaws
(BRONJ) was recognized a few years after their approval for use ${ }^{1}$. Reports first appeared in 2003, alerting the dental and medical communities of this complication ${ }^{28,37,38,43}$. Since brought to light in $2003^{23,47}$, well over 400 reports have been published concerning BRONJ. Despite this large volume of work, there are few data yet many hypotheses concerning the underlying pathophysiology. The physiologic effects of bisphosphonates on bone cells, osteoblasts, osteoclasts, and osteocytes, have recently been comprehensively reviewed $39,40,41$.

Osteoclasts represent the main cellular target of bisphosphonates ${ }^{46}$. Specifically, bisphosphonates repress osteoclast-mediated bone remodeling, through disruption of intracellular pathways. As remodeling is a vital role process in tissue renewal and bone healing, bisphosphonate-induced remodeling suppression causes relevant effects on 


\begin{tabular}{|l|c|c|c|c|}
\hline & Primary Indication & Dose & Route & $\begin{array}{c}\text { Relative } \\
\text { Potency* }\end{array}$ \\
\hline Etidronate & Paget's disease & $300-750 \mathrm{mg}$ daily for $6 \mathrm{months}$ & Oral & 1 \\
\hline Tiludronate & Paget's disease & $400 \mathrm{mg}$ daily for $3 \mathrm{months}$ & Oral & 50 \\
\hline Alendronate & Osteoporosis & $10 \mathrm{mg} / \mathrm{day}$ & Oral & 1,000 \\
& & $70 \mathrm{mg} / \mathrm{week}$ & Oral & Oral \\
\hline Risedronate & Osteoporosis & $5 \mathrm{mg} / \mathrm{day}$ & Oral & 1,000 \\
& & $35 \mathrm{mg} / \mathrm{week}$ & Oral & 1,000 \\
\hline Ibandronate & Osteoporosis & $2.5 \mathrm{mg} / \mathrm{day}$ & Oral & IV \\
& & $150 \mathrm{mg} / \mathrm{months}$ & IV & $1,000-5,000$ \\
\hline Pamidronate & Bone metastases & $3 \mathrm{mg}$ every $3 \mathrm{months}$ & IV & $10,000+$ \\
\hline Zoledronate & Bone metastases & $90 \mathrm{mg} / 3$ weeks & IV & \\
& Osteoporosis & $4 \mathrm{mg} / 3$ weeks & $5 \mathrm{mg} / \mathrm{year}$ & \\
\hline
\end{tabular}

Figure 1- Bisphosphonate preparations currently available in the United States (Abbreviation: Intravenous - IV, *Relative to etidronate)

various tissue-level properties $5,7,27,42$.

The effects of bisphosphonates on osteocytes are less clear and more controversial. There is a high awareness on both direct and indirect effects, most of which are centered around the viability and integrity of these cells and their environment ${ }^{3,31,32}$.

Although systemic bone formation is reduced in the presence of bisphosphonates, this is primarily an indirect consequence of remodeling suppression and the coupling between resorption and formation. At the level of the individual basic multicellular unit, osteoblast activity appears unaffected ${ }^{9,13}$. Reports from small animal models suggest that bisphosphonates may suppress osteoblastic bone formation directly on those surfaces undergoing bone formation without prior resorption (i.e., formation modeling) ${ }^{21}$, although large animal models do not show a similar suppressive effect on periosteal surfaces ${ }^{4,26}$.

In addition, this evidence shows that osteoclasts and/or osteocytes are the main cells of interest for BRONJ pathogenesis. The basic premise of this hypothesis is that the jaw has a high remodeling rate and bisphosphonates suppress remodeling. There is no debate about the latter because this is the principal mechanism of action of bisphosphonates ${ }^{34,40,41}$. It is also clear that remodeling, specifically within the intracortical envelope, is considerably higher in the jaw compared with other skeletal sites. The BRONJ hypothesis thus follows the idea that because remodeling is high in the jaw, and bisphosphonates suppress remodeling, this likely plays a role in the pathophysiology of BRONJ3,24.

Current information on the prevalence and incidence of BRONJ (and much rarer nonbisphosphonate-associated events) is poor. These data are hampered by inconsistent definitions, as well as incomplete reporting. Unfortunately, with current information sources, it is not possible to determine the prevalence or incidence rates ${ }^{16}$.

Strategies for the treatment of patients with, or at risk of, BRONJ were defined in the American Association of Oral and Maxillofacial Surgeons (AAOMS) Position Paper on Bisphosphonate-Related Osteonecrosis of the Jaws (Position Paper) and approved by the Board of Trustees in September $2006^{1}$. The Position Paper was developed by a task force appointed by the Board and composed of clinicians with extensive experience in treating these patients and basic science researchers. The knowledge base and experience in addressing BRONJ has expanded, necessitating modifications and refinements to the original Position Paper. The task force was then called together again in August 2008 to review the 2006 recommendations, appraise the current published data, and revise the Position Paper and recommendations, where indicated. This update contains revisions to the diagnosis and staging and management strategies and highlights the status of basic science research $35,36,38$. The purpose of this updated Position Paper is to provide (Figure 2): 1. Perspectives on the risk of developing BRONJ and the risks and benefits of bisphosphonates to facilitate medical decision-making of both the treating physician and the patient; 2. Guidance to clinicians regarding the differential diagnosis of BRONJ in patients with a history of treatment with intravenous (IV) or oral bisphosphonates; 3 . Guidance to clinicians on possible BRONJ prevention measures and treatment of patients with BRONJ according to the presenting stage of the disease.

The aim of this systematic review was to assess the role of the microsurgical reconstruction of the jaws in patents affected by bisphosphonate- 


\begin{tabular}{|c|c|c|}
\hline BRONJ Stage* & Clinical description & Treatment Strategies $\dagger \ddagger \S$ \\
\hline At risk category & $\begin{array}{c}\text { No apparent necrotic bone in patients who } \\
\text { have been treated with either oral or IV } \\
\text { bisphosphonates }\end{array}$ & No treatment indicated. Patient education. \\
\hline Stage 0 & $\begin{array}{l}\text { No clinical evidence of necrotic bone, but } \\
\text { nonspecific clinical findings and symptoms }\end{array}$ & $\begin{array}{l}\text { Systemic management, including use of pain } \\
\text { medication and antibiotics. }\end{array}$ \\
\hline Stage 1 & $\begin{array}{l}\text { Exposed and necrotic bone in asymptomatic } \\
\text { patients without evidence of infection }\end{array}$ & $\begin{array}{l}\text { Antibacterial mouth rinse. Clinical follow-up on } \\
\text { quarterly basis. Patient education and review of } \\
\text { indications for continued bisphosphonate therapy. }\end{array}$ \\
\hline Stage 2 & $\begin{array}{l}\text { Exposed and necrotic bone associated with } \\
\text { infectin as evidenced by pain and erythema in } \\
\text { region of exposed bone with or without purulent } \\
\text { drainage }\end{array}$ & $\begin{array}{l}\text { Symptomatic treatment with oral antibiotics. Oral } \\
\text { antibacterial mouth rinse. Pain control. Superficial } \\
\text { debridement to relieve soft tissue irritation. }\end{array}$ \\
\hline Stage 3 & $\begin{array}{l}\text { Exposed and necrotic bone in patients with } \\
\text { pain, infection, and one or more of the following: } \\
\text { exposed and necrotic bone extending beyond } \\
\text { the region of alveolar bone (inferior border and } \\
\text { ramus in the mandible, maxillary sinus and } \\
\text { zygoma in the maxilla), resulting in pathologic } \\
\text { fracture, extraoral fistula, oral antral/oral nasal } \\
\text { communication, or osteolysis extending to the } \\
\text { inferior border of the mandible or the sinus floor }\end{array}$ & $\begin{array}{l}\text { Antibacterial mouth rinse. Antibiotic therapy and } \\
\text { pain control. Surgical debridement/resection for } \\
\text { longer term palliation of infection and pain. }\end{array}$ \\
\hline
\end{tabular}

Abbreviations: bisphosphonate-related osteonecrosis of the jaw - BRONJ; intravenous - IV

*Exposed bone in maxillofacial region without resolution within 8-12 weeks in persons treated with bisphosphonate who have not undergone radiotherapy to jaws

†Regardless of disease stage, mobile segments of bone sequestrum should be removed without exposing uninvolved bone; extraction of symptomatic teeth within exposed, necrotic bone should be considered because it is unlikely that extraction will exacerbate established necrotic process

‡Discontinuation of IV bisphosphonates has shown no short-term benefit. However, if systemic conditions permit, longterm discontinuation might be beneficial in stabilizing established sites of BRONJ, reducing risk of new site development, and reducing clinical symptoms. Risks and benefits of continuing bisphosphonate therapy should be made only by treating oncologist in consultation with oral and maxillofacial surgeon and patient

§Discontinuation of oral bisphosphonate therapy in patients with BRONJ has been associated with gradual improvement in clinical disease. Discontinuation of oral bisphosphonates for 6-12 months may result in either spontaneous sequestration or resolution after debridement surgery. If systemic conditions permit, modification or cessation of oral bisphosphonate therapy should be done in consultation with treating physician and patient

Figure 2- Staging and treatment strategies. [Ruggiero, et al. $\left.{ }^{37}(2009)\right]$

related osteonecrosis (Figure 3), highlighting the clinical effectiveness at short- and long-term using the vascularized fibula free flap, and evaluating biological complications after an observation period of at least 12 months in the cases of BRONJ at the $3^{\text {rd }}$ stage (as per Position Paper of American Association of Oral and Maxillofacial Surgeons -AAOMS).

\section{MATERIAL AND METHODS}

\section{Search strategy and inclusion criteria}

A systematic review of the English literature was conducted for selected articles published from January 1976 to June 2009.
Searching was performed using an full-text electronic journal database (PubMed). The following key word combinations were applied: jaw osteonecrosis, osteonecrosis bisphosphonate, bisphosphonate-related osteonecrosis, microsurgical reconstruction of the jaws, vascularized fibula flap. Manual searches of the bibliographies of all full-text articles and related reviews, selected from the electronic search, were also performed. Furthermore, manual searching was conducted in the following journals for the considered period: American Journal Medicine, Bone, British Journal of Oral and Maxillofacial Surgery, Clinical Oral Implants Related Research, Journal of Periodontology, Journal of Oral and Maxillofacial Surgery, Journal of Oral 


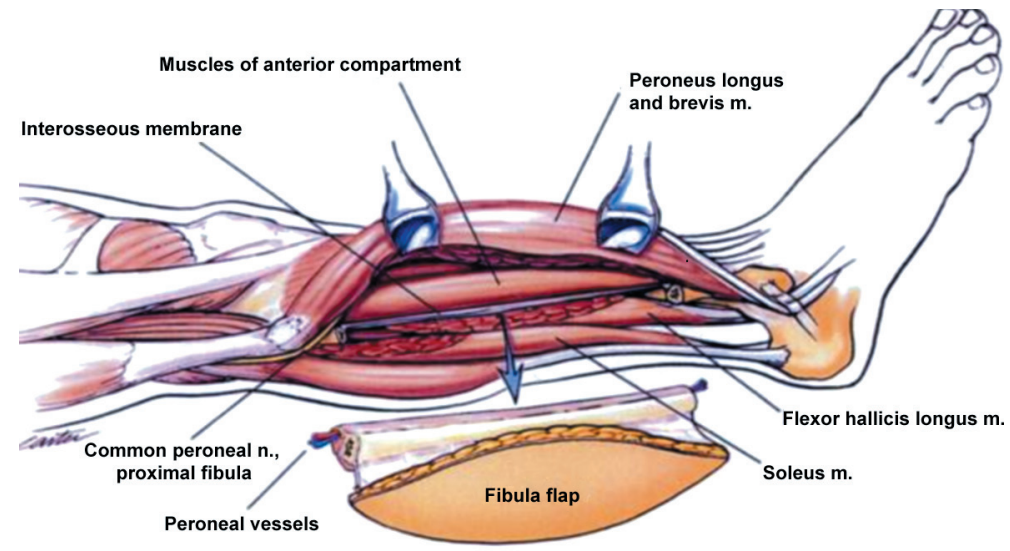

Figure 3- Lateral view of the right leg. Note the proximity of the common peroneal nerve to the proximal osteotomy, according to Anthony and Foster ${ }^{6}$ (1996)

Pathology and Medicine, Journal of Prosthetic Dentistry, Oral Disease, Oral Oncology, Oral Surgery, Oral Medicine, Oral Pathology, Oral Radiology, and Endodontics, Quintessence International and The Laryngoscope.

From this extensive search, it was obvious that there were no randomized controlled clinical trials (RCTs) available, prospective or retrospective studies. In the absence of RCTs, prospective or retrospective studies, this systematic review was based on clinical cases (case series, case report):

- that had a mean follow-up time of 12 months or more;

- obtained from publications within English dental literature;

- where patients included had been examined clinically at follow-up visits.

\section{Selection of studies}

Titles and abstracts of the searches were initially screened by two independent reviewers for possible inclusion in the review. The full text of all relevant studies was then obtained for independent assessment by the reviewers. Any disagreement was resolved by discussion. Figure 4 describes the identification process of the 5 studies which were selected from an initial yield of 947 titles. Data were extracted using a data extraction form. Disagreement regarding data extraction was resolved by consensus, after discussions (Figure 1 ).

\section{Excluded studies}

Six out of 11 full-text articles examined were excluded from the final analysis for different reasons: the mean observation period was $<12$ months, the type of reconstructions was not performed with vascularized fibula flap and/or the osteonecrosis was an osteoradionecrosis.

\section{Data extraction}

Information on the surgical reconstructions and on biological complications was retrieved from the

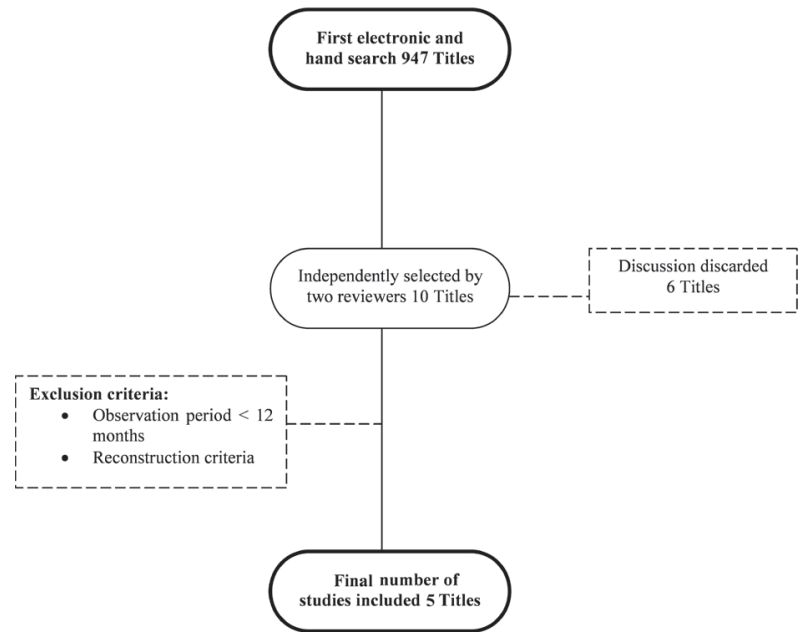

Figure 4- Search strategy

5 included studies. Biological complications during the surgery, after the surgery and in the follow-up period were highlighted.

\section{RESULTS}

A total of 22 patients were observed and treated in 5 different studies where 13 patients received a vascularized osteocutaneous fibula free flap reconstruction (59.09\%) and 9 received only a vascularized fibula free flap reconstruction $(40.90 \%)$ (Figures 5 and 6). All flaps survived completely and the postoperative course was uneventful with cumulative survival rate (CSR) of $100 \%$ (Figure 6). Exceptions were represented by 6 cases $(27.27 \%)$ : four patients $(18.18 \%)$ had postoperative wound complications. The most common complication was fistula which in one case required a pectoralis myogenous flap for wound closure; in another case $(4.54 \%)$, the rupture of a miniplate was observed but it did not require any surgical exploration in a third case $(4.54 \%)$, a small hematoma formed in the anterior portion of the neck incision after approximately 2 weeks from the operation (Figure 7). Two patients died of cancer- 
related disease 8 weeks and 16 month after surgery, with no signs of recurrent BRONJ. BRONJ-related facial pain and halitosis stopped completely after the operation in all patients. The donor leg healed without complications in all cases. Stable oral lining and solid bone union were achieved in all patients. In all studies no complications were reported to the vascularized fibula free flap with $100 \%$ of success rate and recurrence of the osteonecrosis were noted only in two cases (9.09\%) (Figure 7).

\begin{tabular}{|c|c|c|c|c|c|}
\hline Reference & $\begin{array}{c}\text { Number } \\
\text { of } \\
\text { patients }\end{array}$ & $\begin{array}{l}\text { Age of } \\
\text { patients }\end{array}$ & Medical History & $\begin{array}{l}\text { Pharmacological therapy } \\
\text { used by the patients }\end{array}$ & $\begin{array}{c}\text { Mandible } \\
\text { necrosis } \\
\text { involvement }\end{array}$ \\
\hline $\begin{array}{l}\text { Engroff and } \\
\text { Kim }^{12} 2007\end{array}$ & 2 & $\begin{array}{l}56.5 \text { years } \\
\text { (mean) }\end{array}$ & 2 Breast cancer & $\begin{array}{l}1 \mathrm{Pz} . \text { IV Zoledronate; } \\
1 \mathrm{Pz} . \text { OS pamidronate }\end{array}$ & Partially \\
\hline $\begin{array}{l}\text { Ferrari, et al. }{ }^{15} \\
2008 \\
\end{array}$ & 1 & $\begin{array}{c}66 \text { years } \\
\text { old }\end{array}$ & 1 Multiple myeloma & $\begin{array}{c}1 \mathrm{Pz} . \text { IV pamidronate and later } \\
\text { Zoledronate }\end{array}$ & Totally \\
\hline $\begin{array}{l}\text { Mucke, et al. }{ }^{28} \\
2009 \\
\end{array}$ & 1 & $\begin{array}{l}60 \text { years } \\
\text { old }\end{array}$ & 1 Multiple myeloma & $1 \mathrm{Pz}$. IV Zoledronate & Partially \\
\hline $\begin{array}{l}\text { Nocini, et al.29 } \\
2009\end{array}$ & 7 & $\begin{array}{l}61 \text { years } \\
\text { (mean) }\end{array}$ & $\begin{array}{c}\text { Pz. Breast cancer; } 1 \\
\text { Pz. Prostate cancer; } \\
1 \text { Pz. Multiple } \\
\text { myeloma }\end{array}$ & $\begin{array}{c}5 \text { Pz. IV pamidronate and later } \\
\text { Zoledronate; } \\
2 \mathrm{Pz} \text {. IV Zoledronate }\end{array}$ & $\begin{array}{l}2 \text { Totally, } \\
6 \text { Partially }\end{array}$ \\
\hline $\begin{array}{c}\text { Seth, et al. }{ }^{43} \\
2010\end{array}$ & 11 & $\begin{array}{l}61.3 \text { years } \\
\text { (mean) }\end{array}$ & $\begin{array}{l}5 \text { Pz. Breast cancer; } 2 \\
\text { Pz. Prostate cancer; } \\
2 \text { Pz Multiple myeloma } \\
2 \text { Pz. Osteoporosis }\end{array}$ & $\begin{array}{l}6 \text { Pz. IV Zoledronate; } \\
2 \text { Pz. OS Alendronate; } \\
2 \text { Pz. OS Ibandronate; } \\
1 \text { Pz. IV Etidronate }\end{array}$ & 11 Partially \\
\hline
\end{tabular}

Figure 5- Studies retrieved from the review of the literature: analysis of medical history, type of therapy used and mandible necrosis involved

\begin{tabular}{|c|c|c|c|c|c|c|}
\hline Reference & $\begin{array}{c}\text { Number of } \\
\text { patients }\end{array}$ & $\begin{array}{l}\text { Type of } \\
\text { study }\end{array}$ & $\begin{array}{l}\text { Type of } \\
\text { surgery }\end{array}$ & $\begin{array}{c}\text { Type of } \\
\text { technique }\end{array}$ & $\begin{array}{l}\text { Cumulative } \\
\text { survive rate } \\
\text { of the grafts } \\
\text { (CSR) }\end{array}$ & $\begin{array}{l}\text { Years of } \\
\text { follow-up }\end{array}$ \\
\hline $\begin{array}{l}\text { Engroff and Kim }{ }^{12} \\
2007\end{array}$ & 2 & Case series & $\begin{array}{c}\text { Partial } \\
\text { resection }\end{array}$ & $\begin{array}{l}\text { Vascularized } \\
\text { fibula free flap }\end{array}$ & $100 \%$ & $\begin{array}{c}12 \\
\text { months } \\
\end{array}$ \\
\hline Ferrari, et al. ${ }^{15} 2008$ & 1 & Case report & Total resection & $\begin{array}{l}\text { Vascularized } \\
\text { fibula free flap }\end{array}$ & $100 \%$ & $\begin{array}{c}12 \\
\text { months }\end{array}$ \\
\hline Mucke, et al. ${ }^{28} 2009$ & 1 & Case report & $\begin{array}{c}\text { Partial } \\
\text { resection }\end{array}$ & $\begin{array}{c}\text { Vascularized } \\
\text { fibula } \\
\text { osteocutaneous } \\
\text { free flap } \\
\end{array}$ & $100 \%$ & $\begin{array}{c}12 \\
\text { months }\end{array}$ \\
\hline Nocini, et al. ${ }^{29} 2009$ & 7 & Case series & $\begin{array}{c}\text { Partial } \\
\text { resection } \\
\text { and } \\
\text { Total resection }\end{array}$ & $\begin{array}{c}\text { Vascularized } \\
\text { fibula free flap } \\
\text { and } \\
\text { Vascularized } \\
\text { fibula } \\
\text { osteocutaneous } \\
\text { free flap }\end{array}$ & $100 \%$ & $\begin{array}{l}\text { Range: } \\
6 \text { to } 34 \\
\text { months }\end{array}$ \\
\hline Seth, et al. ${ }^{43} 2010$ & 11 & Case series & $\begin{array}{l}\text { Partial } \\
\text { resection }\end{array}$ & $\begin{array}{c}\text { Vascularized } \\
\text { fibula } \\
\text { osteocutaneous } \\
\text { free flap }\end{array}$ & $100 \%$ & $\begin{array}{l}\text { Range: } \\
2 \text { weeks } \\
\text { to } 31 \\
\text { months }\end{array}$ \\
\hline
\end{tabular}

Figure 6- Studies retrieved from the review of the literature: analysis of type of surgery, type of graft used, cumulative survival rate of the grafts and years of follow-up 


\begin{tabular}{|c|c|c|c|c|c|}
\hline Reference & $\begin{array}{l}\text { Number } \\
\text { of } \\
\text { patients }\end{array}$ & Kind of graft used & $\begin{array}{l}\text { Suggestions } \\
\text { before surgery }\end{array}$ & $\begin{array}{l}\text { Postoperative } \\
\text { complication }\end{array}$ & BRONJ recurrences \\
\hline $\begin{array}{l}\text { Engroff and } \\
\text { Kim }^{12} 2007\end{array}$ & 2 & $\begin{array}{c}2 \text { patients were } \\
\text { reconstructed with an } \\
\text { FFF }\end{array}$ & ND & $\begin{array}{c}1 \text { postoperative } \\
\text { neck hematoma, } \\
\text { drained at bedside }\end{array}$ & $\begin{array}{c}1 \text { patient developed } \\
\text { contralateral } \\
\text { mandible BRONJ, } \\
\text { managed } \\
\text { conservatively }\end{array}$ \\
\hline $\begin{array}{c}\text { Ferrari, et al. }{ }^{15} \\
2008\end{array}$ & 1 & $\begin{array}{c}1 \text { patient were } \\
\text { reconstructed with FFF }\end{array}$ & ND & None & None \\
\hline $\begin{array}{c}\text { Mucke, et al. }{ }^{28} \\
2009\end{array}$ & 1 & $\begin{array}{c}1 \text { patient were } \\
\text { reconstructed with OFFF }\end{array}$ & ND & None & None \\
\hline $\begin{array}{l}\text { Nocini, et al. }{ }^{29} \\
2009\end{array}$ & 7 & $\begin{array}{c}6 \text { patients were } \\
\text { reconstructed with an } \\
\text { FFF and } 1 \text { with an OFFF }\end{array}$ & $\begin{array}{c}\text { B therapy was } \\
\text { interrupted and } 25 \\
\text { preoperative } \\
\text { sessions of (HBO) }\end{array}$ & $\begin{array}{c}1 \text { Rupture of a } \\
\text { miniplate }\end{array}$ & $\begin{array}{l}1 \text { patient with short- } \\
\text { term recurrence at } \\
\text { resection margin, } \\
\text { resolved }\end{array}$ \\
\hline $\begin{array}{l}\text { Seth, et al. }{ }^{43} \\
2010\end{array}$ & 11 & $\begin{array}{c}11 \text { patients were } \\
\text { reconstructed with OFFF }\end{array}$ & ND & $\begin{array}{c}4 \text { cases fistula } \\
\text { and infection, all } \\
\text { reselved }\end{array}$ & None \\
\hline
\end{tabular}

Figure 7- Studies retrieved from the review of the literature: analysis of type of reconstruction (fibula free flap - FFF and osteocutaneous fibula free flap - OFFF), particular procedures before surgery (hyperbaric oxygen therapy - HBO), postoperative wound complications and bisphosphonate-related osteonecrosis of jaws (BRONJ) recurrences

\section{DISCUSSION}

BRONJ is a challenging complication to treat, in terms of both disease control and quality of life 2,46 , and its treatment is still under discussion and unclear. Although recommendations for the management of this disease exist, they are dependent on a small group of patients. In addition, accordance about prevention or conservative treatment as the basis for "at risk" patients exist ${ }^{18,23,25}$. Medical treatments are routinely employed together with conservative surgery of the exposed necrotic bone ${ }^{22}$. However, the initial treatment should include improvement of oral hygiene and systemic antibiotics to prevent secondary infection and pain ${ }^{8,14}$.

For the management of exposed necrotic bone, additional surgical debridement or sequestrectomy with primary mucosal closure seems to be effective in most cases. If there are recurrences at the conservative treatment, bone segment should be considered as it seems to be more successful than wound debridement alone ${ }^{29}$.

The reconstruction of subtotal mandibulectomy defects requires vascularized bone to promote healing and provide adequate soft-tissue support and oral competence ${ }^{11,45}$. Engroff and $\mathrm{Kim}^{12}$ (2007), reported two cases of microvascular reconstruction of the mandible in BRONJ patients. Two lateral mandibular defects were successfully reconstructed with a fibula flap ${ }^{12}$.

Nocini, et al.30 (2009) in their case series have recently shown that a properly planned surgical resection has high curative potential in BRONJ patients. Mucke, et al. ${ }^{29}$ (2009) have shown that the effect of the transferred flap with also the vascularized iliac crest might represent a valuable technique. Despite the co-morbid conditions, the free bone-flap survival, the overall morbidity and the hospital stay, patients treated for osteonecrosis were comparable to that of patients whose mandibles are reconstructed because of osteoradionecrosis ${ }^{10,17}$.

Patients with reasonable life expectancy with regard to their malignant disease should be considered for microvascular tissue transfer after aggressive resection of the affected region. The quality of life can be increased and a subset of patients with advanced disease can be cured of BRONJ. As already mentioned, the basic pathogenesis of this disease seems to be an avascular osteonecrosis, particularly involving the jaws. It seems therefore to be possible to treat patients with microvascular reconstruction of the jaws as the transferred bone receives direct blood supplementation from the anastomosed artery (superior thyroid or facial artery). The effect of the transferred flap with a new input of blood supply might be one of the reasons for the uneventful postoperative course in all patients. However, the cutaneous component of the flap provides additional soft tissue for reconstruction of resected fistulas and helps establish tension free wounds in the oral cavity. Seth, et al. ${ }^{44}$ (2010) have shown recently that vascularized bone graft reconstruction with osteocutaneous fibula free flap is feasible, offers a high success rate with only few postoperative wound 
complications selected patients with advanced cases of BRONJ.

According to literature ${ }^{12,15,29,30,44}$, radical surgical treatment has to be considered when:

- BRONJ seems to involve a large area of the jaws;

- the disease is not resolved by conservative therapy;

- the donor site of the patient is well perfused;

- the donor site of the patient is excluded by bone metastases.

However, the possibility of transferring cancer cells to the oral cavity during jawbone reconstruction with free bone flaps in patients with disseminated cancer or multiple myeloma has not been observed. Furthermore, fibula is rarely the site of metastatic bone disease or multiple myeloma ${ }^{20}$. Mandibular reconstruction using bone-containing microvascular flaps such as a fibula free flap is possible after a large resection and it gives also the opportunity of oral prosthetic rehabilitation using dental implants, as described by Ferrari, et al. ${ }^{15}$ (2008) in their clinical report.

\section{CONCLUSIONS}

Osteonecrosis is a rare but significant complication of bisphosphonate therapy, and current literature supports only conservative defect reconstruction. These measures may not provide optimum reconstruction to achieve a well-vascularized healing environment, adequate oral function, and facial cosmetics. Microsurgical reconstruction of the jaws plays a critical role in improving the patient's quality of life. After an observation period of 12 months from microsurgical reconstruction of the jaws, high survival rates can be expected with few recurrences of osteonecrosis (9.09\%). This, in turn, means that vascularized fibula flap technique has been well accepted by the clinician findings. Despite the limited number of patients found in the review of literature, this kind of treatment appears to be practicable in BRONJ-resected patients and does not seem to influence the natural course of the primary disease.

\section{REFERENCES}

1- Advisory Task Force on Bisphosphonate-Related Osteonecrosis of the Jaws. American Association of Oral and Maxillofacial Surgeons. American Association of Oral and Maxillofacial Surgeons position paper on bisphosphonate-related osteonecrosis of the jaws. J Oral Maxillofac Surg. 2007;65:369-76.

2- Agrillo A, Ungari C, Filiaci F, Priore P, Iannetti G. Ozone therapy in the treatment of avascular bisphosphonate-related jaw osteonecrosis. J Craniofac Surg. 2007;18:1071-5.

3- Allen MR, Burr DB. Mandible matrix necrosis in beagle dogs after 3 years of daily oral bisphosphonate treatment. J Oral Maxillofac Surg. 2008;66:987-94.
4- Allen MR, Follet $\mathrm{H}$, Khurana M, Sato M, Burr DB. Antiremodeling agents influence osteoblast activity differently in modeling and remodelling sites of canine rib. Calcif Tissue Int. 2006;79:255-61. 5- Allen MR, Iwata K, Phipps R, Burr DB. Alterations in canine vertebral bone turnover, microdamage accumulation, and biomechanical properties following 1-year treatment with clinical treatment doses of risedronate or alendronate. Bone. 2006;39:872-9.

6- Anthony JP, Foster RD. Mandibular reconstruction with the fibula osteocutaneous free flap. Oper Tech Plast Rec Surg. $1996 ; 3(4): 233-40$

7- Arantes HP, Silva AG, Lazaretti-Castro M. Bisphosphonates in the treatment of metabolic bone diseases. Arq Bras Endocrinol Metab. 2010;54:206-12.

8- Assael LA. New foundations in understanding osteonecrosis of the jaws. J Oral Maxillofac Surg. 2007;62:125-6.

9- Boyce RW, Paddock CL, Gleason JR, Sletsema WK, Eriksen EF. The effects of risedronate on canine cancellous bone remodeling: three-dimensional kinetic reconstruction of the remodeling site. J Bone Miner Res. 1995;10:211-21.

10- Buchbinder D, St. Hilaire $H$. The use of free tissue transfer in advanced osteoradionecrosis of the mandible. J Oral Maxillofac Surg. 2006;64:961-4.

11- Duncan MJ, Manktelow RT, Zuker RM, Rosen IB. Mandibular reconstruction in the radiated patient: the role of osteocutaneous free tissue transfers. Plast Reconstr Surg. 1985;76:829-40.

12- Engroff LS, Kim DD. Treating bisphosphonate osteonecrosis of the jaws: is there a role for resection and vascularized reconstruction? J Oral Maxillofac Surg. 2007;65:2374-85.

13- Eriksen EF, Melsen F, Sod E, Barton I, Chines A. Effects of long-term risedronate on bone quality and bone turnover in women with postmenopausal osteoporosis. Bone. 2002;31:620-5.

14- Farrugia MC, Summerlin DJ, Krowiak E, Huntley T, Freeman $\mathrm{S}$, Borrowdale $\mathrm{R}$, et al. Osteonecrosis of the mandible or maxilla associated with the use of new generation bisphosphonates. Laryngoscope. 2006;116:115-20.

15- Ferrari S, Bianchi B, Savi A, Poli T, Multinu A, Balestreri A. Fibula free flap with endosseous implants for reconstructing a resected mandible in bisphosphonate osteonecrosis. J Oral Maxillofac Surg. 2008;66:999-1003.

16- Gliklich R, Wilson J. Epidemiology of bisphosphonate-related osteonecrosis of the jaws: the utility of a national registry. J Oral Maxillofac Surg. 2009;67(Sp. Iss. 5):71-4.

17- Goodacre TE, Walker CJ, Jawad AS, Jackson AM, Brough MD. Donor site morbidity following osteocutaneous free fibula transfer. Br J Plast Surg. 1990;43:410-2.

18- Greenberg MS. Intravenous bisphosphonates and osteonecrosis. Oral Surg Oral Med Oral Pathol Oral Radiol Endod. 2004; 98:259-60.

19- Griz L, Caldas G, Bandeira C, Assunção V, Bandeira F. Paget's disease of bone. Arq Bras Endocrinol Metabol. 2006;50:814-22. 20- Hsu CC, Chuang YW, Lin CY, Huang YF. Solitary fibular metastasis from lung cancer mimicking stress fracture. Clin Nucl Med. 2006;31:269-71.

21- Iwata K, Li J, Follet H, Phipps RJ, Burr DB. Bisphosphonates suppress periosteal osteoblast activity independently of resorption in rat femur and tibia. Bone. 2006;39:1053-8.

22- Khosla S, Burr D, Cauley J, Dempster DW, Ebeling PR, Felsenberg $D$, et al. Bisphosphonate-associated osteonecrosis of the jaw: report of a task force of the American Society for Bone and Mineral Research. J Bone Miner Res. 2007;22:1479-91.

23- Marx RE. Pamidronate (Aredia) and zoledronate (Zometa) induced avascular necrosis of the jaws: a growing epidemic. J Oral Maxillofac Surg. 2003;61:1115-7.

24- Marx RE, Cillo JE Jr, Ulloa JJ. Oral bisphosphonate-induced osteonecrosis: risk factors, prediction of risk using serum CTX testing, prevention, and treatment. J Oral Maxillofac Surg. 2007;65:2397-410. 
25- Marx RE, Sawatari Y, Fortin M, Broumand V. Bisphosphonateinduced exposed bone (osteonecrosis/osteopetrosis) of the jaws: risk factors, recognition, prevention, and treatment. J Oral Maxillofac Surg. 2005;63:1567-75.

26- Mashiba T, Hirano T, Turner $\mathrm{CH}$, Forwood MR, Johnston CC, Burr DB. Suppressed bone turnover by bisphosphonates increases microdamage accumulation and reduces some biomechanical properties in dog rib. J Bone Miner Res. 2000;15(4):613-20.

27- McDonald MM, Dulai S, Godfrey C, Amanat N, Sztynda T, Little DG. Bolus or weekly zoledronic acid administration does not delay endochondral fracture repair but weekly dosing enhances delays in hard callus remodeling. Bone. 2008;43:653-62.

28- Migliorati CA. Bisphosphonates and oral cavity avascular bone necrosis. J Clin Oncol. 2003;21:4253-4.

29- Mücke T, Haarmann S, Wolff KD, Hölzle F. Bisphosphonate related osteonecrosis of the jaws treated by surgical resection and immediate osseous microvascular reconstruction. ] Craniomaxillofacial Surg. 2009;37:291-7.

30- Nocini PF, Saia G, Bettini G, Ragazzo M, Blandamura S, Chiarini $L$, et al. Vascularized fibula flap reconstruction of the mandible in bisphosphonate-related osteonecrosis. Eur J Surg Oncol. 2009;35:373-9.

31- Plotkin LI, Aguirre JI, Kousteni S, Manolagas SC, Bellido T. Bisphosphonates and estrogens inhibit osteocyte apoptosis via distinct molecular mechanisms downstream of extracellular signalregulated kinase activation. J Biol Chem. 2005;280:7317-25.

32- Plotkin LI, Weinstein RS, Parfitt AM, Roberson PK, Manolagas SC, Bellido T. Prevention of osteocyte and osteoblast apoptosis by bisphosphonates and calcitonin. J Clin Invest. 1999;104:1363-74 33- Reiriz AB, De Zorzi PM, Lovat CP. Bisphosphonates and osteonecrosis of the jaw: a case report. Clinics (Sao Paulo). 2008;63:281-4.

34- Rodan GA, Fleisch HA. Bisphosphonates: mechanisms of action. J Clin Invest. 1996;97:2692-6.

35- Rosen HN, Moses AC, Garber J, Iloputaife ID, Ross DS, Lee SL, Greenspan SL. Serum CTX: a new marker of bone resorption that shows treatment effect more often than other markers because of low coefficient of variability and large changes with bisphosphonate therapy. Calcif Tissue Int. 2000;66:100-3.

36- Rosen HN, Moses AC, Garber J, Ross DS, Lee SL, Greenspan $\mathrm{SL}$. Utility of biochemical markers of bone turnover in the followup of patients treated with bisphosphonates. Calcif Tissue Int. 1998;63:363-8.
37- Rosenberg TJ, Ruggiero S. Osteonecrosis of the jaws associated with the use of bisphosphonates. J Oral Maxillofac Surg. 2003;61(Sp. Iss.):60.

38- Ruggiero SL, Dodson TB, Assael LA, Landesberg R, Marx RE. Mehrotra $B$, et al. American Association of Oral and Maxillofacial Surgeons position paper on bisphosphonate-related osteonecrosis of the jaw - 2009 update. J Oral Maxillofac Surg. 2009;35:119-30. 39- Ruggiero SL, Mehrotra B, Rosenberg TJ, Engroff SL. Osteonecrosis of the jaws associated with the use of bisphosphonates: a review of 63 cases. J Oral Maxillofac Surg. 2004;62:527-34.

40- Russell RG, Watts NB, Ebetino FH, Rogers MJ. Mechanisms of action of bisphosphonates: similarities and differences and their potential influence on clinical efficacy. Osteoporos Int. 2008;19:733-59.

41- Russell RG, Xia Z, Dunford JE, Oppermann U, Kwaasi A, Hulley PA, et al. Bisphosphonates: an update on mechanisms of action and how these relate to clinical efficacy. Ann N Y Acad Sci. 2007;1117:209-57.

42- Santamaria Júnior M, Fracalossi AC, Consolaro MF, Consolaro A. Influence of bisphosphonates on alveolar bone density: a histomorphometric analysis. Braz Oral Res. 2010;24:309-15.

43- Sarathy AP, Bourgeois SL Jr, Goodell GG. Bisphosphonateassociated osteonecrosis of the jaws and endodontic treatment: two case reports. J Endod. 2005;31:759-63.

44- Seth R, Futran ND, Alam DS, Knott PD. Outcomes of vascularized bone graft reconstruction of the mandible in bisphosphonate-related osteonecrosis of the jaws. Laryngoscope. 2010;120:2165-71.

45- Urken ML. Composite free flaps in oromandibular reconstruction. Review of the literature. Arch Otolaryngol Head Neck Surg. 1991; 117:724-32.

46- Vescovi P, Merigo E, Meleti M, Fornaini C, Nammour S, Manfredi M. Nd:YAG laser biostimulation of bisphosphonate-associated necrosis of the jawbone with and without surgical treatment. $\mathrm{Br}$ J Oral Maxillofac Surg. 2007;45:628-32.

47- Wang J, Goodger NM, Pogrel MA. Osteonecrosis of the jaws associated with cancer chemotherapy. J Oral Maxillofac Surg. 2003;61:1104-7. 